\section{GREEN LEAVES AS A SOURCE OF PROTEINS AND OTHER NUTRIENTS}

$T \mathrm{~T}$ is natural that the restriction of imports, and the changes in our dietetic habits that this has necessitated, should quicken our interest in the efficient production of food in Great Britain. In a few quarters, notably the immediate vicinity of the Ministry of Food, it is maintained that there is not now, and is not likely to be in the later stages of the War, a food shortage. Fortunately for the country most scientific workers concerned with nutrition or agriculture do not share this complacent attitude. Their interest was clearly shown at the discussion organized on February 11 by the Nutrition Panel of the Food Group of the Society of Chemical Industry. The papers read dealt mainly with carotene and other lipoids; there was discussion on this subject and on a project that had been circulated beforehand dealing with the large-scale isolation of protein from leaves for the feeding of people and other non-ruminants.

The vitamin content of leaves was compared with that of various other plant products by V. H. Booth. When taken at the right time of year leaves constitute a valuable source of ascorbic acid and of carotene, but ascorbic oxidase is so widespread that it is unlikely that products derived from leaves would be of much value in practice as sources of ascorbic acid. Samples of lard containing enough carotene to give 640 I.U. per ounce (the amount officially added to margarine) were shown and also samples in which only partially fractionated grass fat had been added to give the same carotene content. The former were about as dark as normal margarine and the latter, though darker, were not unpleasantly so. It was clear, from this survey, that leaves are not of great significance as a source of any of the other vitamins except K.

During storage, the carotene content of grounddried lucerne leaves falls. R. O. Davies described this phenomenon in some detail and pointed out that the loss was only significant if the leaf meal was not cooled after coming from the drying plant and before storage. The fall is not continuous but a steady state is reached after 1-2 weeks; A. C. Pollard, on the other hand, found a continuous fall in the carotene content of ground-dried carrot pulp. No wholly satisfactory explanation of this difference was given, but it was suggested that there may be more than one isomer of carotene present; that carotene may only be readily oxidized in those cells that have been thoroughly damaged by the grinding; that there may be a difference in the oxidizability of carotene in the free and proteinbound states. The other lipoids of the leaf were described by H. S. Jefferies. 4 per cent of dried lucerne leaves is soluble in benzene and half of this dissolves in acetone. Phosphatides constitute 35-37 per cent of the total lipoids-an unusually high phosphatide/fat ratio. Less than 3 per cent of the lipoid is sterol and there appears to be no ergosterol in lucerne although the lipoids from grasses have been shown to contain about I per cent.

In the contribution taken as read at the meeting ${ }^{1}$ it had been urged that research should be undertaken on the separation and purification of leaf protein and on the cultivation of crops that would give a good yield of protein per acre coupled with a leaf that, in terms of its dry weight, was rich in protein. The most immediately available material for this research would be the normal pasture mixture, but special grass mixtures or crops such as lucerne or maize may well turn out to be the most suitable in practice. The fresh leaves would be macerated and a protein. rich liquor separated from the leaf residue; the protein can readily be separated from the liquor by a number of treatments such as heat coagulation. Experience gained in the course of work on the pigments, enzymes and viruses in leaves suggests that about one third of the protein can easily be liberated in this way; a rather larger proportion comes out if the original crude protein content of the leaf is high, that is, more than 18 per cent. The leaf residue would therefore still contain about two thirds of the protein as well as all the fibre. From 140,000 acres it should be possible to prepare sufficient leaf protein to supply $1 \mathrm{gm}$. per head of population every day for a year. The aim of the research would therefore be to 'skim' off part of the protein of the leaf in a form suitable for the non-ruminant while leaving a residue suitable for use as a feeding-stuff for ruminants. If the research were successful, several advantages are claimed for this method of husbandry. The yield of protein of high biological value would be higher than that attainable from an acre by any other means; the fibre residue would be of relatively constant composition and of considerably greater feeding value than the hay that would probably have been made on the land had it not been used for this purpose; there is good reason to think that leaf protein would cost less than the other proteins that can be produced in Great Britain.

A. C. Chibnall agreed with the general principle of leaf protein extraction, but thought that it would be premature to start any research on these lines until our agricultural policy had undergone thorough reorganization. Difficulties were predicted both in the operation of an acreage sufficient to make a significant contribution to our protein supply and in the maintenance of a high leaf protein content. These difficulties did not impress R. O. Davies who has experience of farming more than ten thousand acres of lucerne; for five months out of the year the crop contained 17-28 per cent of crude protein.

Figures for the amino acid composition of protein isolated from cocksfoot grass were given by A. C. Chibnall, and he pointed out that this fraction of the total leaf protein contains all the amino acids that are known to be essential in the nutrition of the rat, in about the right amounts. Estimations of some of the amino acids in proteins from the leaves of several plants suggest that these proteins form a group of fairly uniform composition and of high 'biological value'. The need for feeding experiments to supplement these analyses was stressed by S. K. Kon, for leaf protein fed in the form of dried grass had a lower 'biological value' than Chibnall's figures would lead one to expect. These experiments, as A. L. Bacharach pointed out, should not be confined to the rat, but should be extended to some of the animals in the nutrition of which we are more immediately interested.

N. W. Pirie.

1 N. W. Pirie, "The Direct Use of Leaf Protein in Human Nutrition", Chem. and Ind., 61, 45 (1942). 